\title{
An Application of Cloud Computing Based Industrial Internet of Things for Generator System
}

\author{
Batın DEMIRCAN ${ }^{1 *}$, Ersin AKYÜZ ${ }^{2}$
}

\begin{abstract}
With the transformation of Industry 4.0, the current understanding of production in the industry is being reshaped together with information technologies. Internet of things and cloud computing are the most important components of this transformation. In this study, the generator system producing electricity as a simulation of an industrial system was used as the main system. 3-phase driven by an internal combustion engine, $\mathrm{AC}$ alternator voltage, current, frequency, alternator temperature and so on, and for the internal combustion engine that provides mechanical drive, oil / water pressure, oil / water temperature, fuel level, etc. The electrical and physical quantities are measured by means of PLC and sensors. It is provided to monitor this measurement data of the generator system both locally via HMI screen and computer screen and as a remote point in Web-based format. RS485 standard has been used together with MQTT protocol which is becoming more and more widespread nowadays and Modbus protocol which is used frequently in industrial systems in both physical and electrical measurements for user viewing and transfer to cloud information system. The measurement data were recorded in the Azure cloud computing system for the performance evaluation of the diesel fuel generator. Firstly, user interface was developed in Node-Red software running on Raspberry Pi. And as a second method, the same application structure is provided with a user interface created on Labview software running on Windows based operating system. In addition, real-time measurement analysis is provided by monitoring data remotely via the PowerBI internet platform.
\end{abstract}

Keywords: Internet of Things, Cloud Computing, Industry 4.0, Labview, Generator.

\section{Jeneratör Sistemi için Bulut Bilişim Tabanlı Endüstriyel Nesnelerin İnterneti Uygulaması}

ÖZET: Endüstri 4.0 dönüşümü ile sanayideki mevcut üretim anlayışı, bilişim teknolojileri ile birlikte yeniden şekillenmektedir. Nesnelerin interneti ve bulut bilişim bu dönüşümün en önemli bileşenleri olarak karşımıza çıkmaktadır. Bu çalışmada, endüstriyel bir sistemin benzetimi olarak elektrik üretimi yapan jeneratör sistemi ana sistem olarak kullanılmıştır. İçten yanmalı bir motor ile tahrik edilen 3 fazlı, AC alternatör için gerilim, akım, frekans, alternatör sıcaklığı vb. ve mekanik tahrik sağlayan içten yanmalı motor için ise yağ/su basıncı, yağ/su sıcaklığı, yakıt seviyesi vb. elektriksel ve fiziksel büyüklükler PLC ve sensörler aracılı̆̆ ölçümlenmiştir. Jeneratör sistemine ait bu ölçüm verilerinin hem bölgesel olarak HMI ekran ile bilgisayar ekranı üzerinden hem de uzak bir nokta olarak Web tabanlı biçimde izlenmesi sağlanmıştır. Fiziksel ve elektriksel ölçümlerin gerek kullanıcı için görüntülenmesinde gerekse bulut bilişim sistemine aktarılmasında; günümüzde gittikçe yaygınlaşan ve yeni bir protokol olan MQTT haberleşme protokolü ve endüstriyel sistemlerde sıkça kullanılan Modbus protokolü ile birlikte RS485 haberleşme standardı kullanılmıştır. Ölçüm verileri, dizel yakıt ile çalışan jeneratörün performans değerlendirmesinde kullanılmak üzere Microsoft Azure bulut bilişim sisteminde kayıt altına alınmıştır. Bunu sağlamak için ilk olarak Raspberry Pi üzerinde çalışan Node-Red yazılımı kullanılmıştır. İkinci olarak ise aynı uygulama yapısı Windows tabanlı işletim sistemi üzerinde çalışan Labview yazılımı üzerinde oluşturulan bir kullanıcı arayüzü ile sağlanmıştır. Ayrıca Microsoft PowerBI internet platformu ile verilerin internet üzerinden uzaktan izlenmesi ile anlık olarak canlı ölçüm analizlerinin yapılması sağlanmıştır.

Anahtar Kelimeler: Nesnelerin İnterneti, Bulut Bilişim, Endüstri 4.0, Labview, Jeneratör.

\footnotetext{
${ }^{1}$ Batın DEMİRCAN (Orcid ID: 0000-0002-0765-458X), İŞBİR Elektrik San. A.Ş., Ar-Ge Merkezi, Balıkesir, Türkiye

${ }^{2}$ Ersin AKYÜZ (Orcid ID: 0000-0001-9786-3221), Balıkesir Üniversitesi, Balıkesir Meslek Yüksekokulu, Elektronik ve Otomasyon Bölümü/Kontrol ve Otomasyon Teknolojisi Pr., Balıkesir, Türkiye

*Sorumlu Yazar/Corresponding Author: Batın DEMIRCAN, e-mail: batindemircan@gmail.com

Geliş tarihi / Received: 12-11-2019

Kabul tarihi / Accepted: 12-01-2020
} 


\section{INTRODUCTION}

Today, Industry 4.0 transformation is seen as an important opportunity to gain competitive advantage in industrial production. With this transition, a great transformation will be achieved in production with the use of structures such as internet of things (IoT), cloud computing, big data and cyber-physical systems in integrated and fully automated systems in industry (Numanoğlu and İnce, 2017). In addition to the flexible production structure that will be provided as a result of this transformation, leading countries in industrial production such as Germany foresee to reduce their costs by $20 \%$ (Numanoğlu et al., 2016).

IoT emerged as a concept by Kevin Ashton in 1999 and is seen as the most important component of the Industrial 4.0 revolution. In its broadest definition, it is defined as a world-wide network of uniquely addressable objects and the communication of objects in this system with a communication protocol (Gündüz and Daş, 2017). Today, the IoT is developing along with the basic issues of reliability, performance, security and privacy. It is estimated that the number of interconnected objects in the world will increase rapidly, surpassing the world population in 2011 and this number will be over 13 billion in 2020 (Botta et al., 2016; Fioccola et al., 2016).

Sensor that communicates with the sensors wired connection in industrial production systems, solenoid valves, programmable logic controllers (PLC) and is widely used architecture employing embedded SCADA system. SCADA as shown in Figure 1 architecture in industrial monitoring and data collection points and local networks are generally limited to use with the data recording facility. With the Industry 4.0 transformation, today's industrial automation systems are entering a new transition and this structure together with sensor networks connected to the internet network, develops applications including cloud systems and creates a smart production structure. This rapidly developing concept is called the "Industrial Internet of Things" (IIoT) (Lin et al., 2016; Brette et al., 2014).

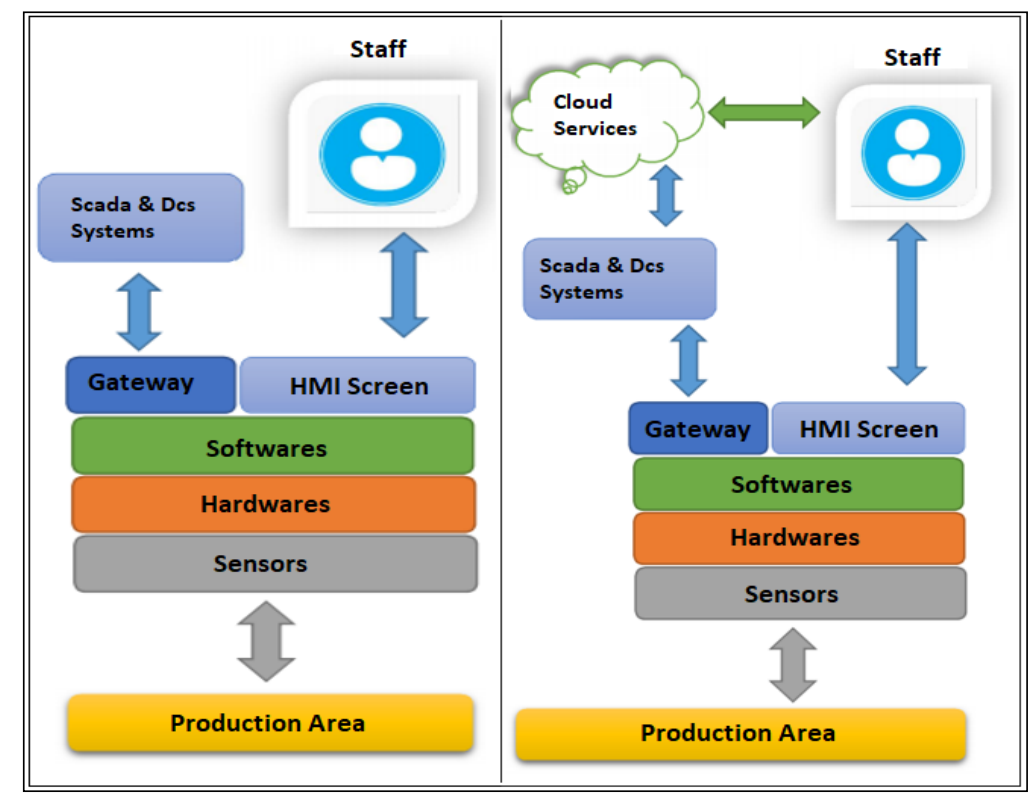

Figure 1. SCADA production architecture and cloud compute-based SCADA production architecture.

SCADA structures are being used in industry together with the rapidly expanding cloud technologies to store and analyze large amounts of data generated by IoT devices. It is clear that the technologies which bring cloud technologies and IoT systems together will affect the internet structure. The new structure created by using the above mentioned IoT and cloud concept is defined as Cloud-IoT (Ficcola et al., 2016). 
The advantages gained by a generator with traditional control structure and the designed cloudbased IoT structure are given in Table 1 in terms of functionality, remote access, integration, maintenance and performance.

Table 1. The comparison for the generator control system

\begin{tabular}{|c|c|c|}
\hline Feature & Standard Control Panel Structure & $\begin{array}{c}\text { IoT System Structure Comprising Node- } \\
\text { Red and Labview }\end{array}$ \\
\hline Functionality & $\begin{array}{l}\text { Product capabilities are limited to those } \\
\text { specified in the product datasheet, } \\
\text { functionality can be provided to a certain } \\
\text { extent if additional modules are provided to } \\
\text { the user. }\end{array}$ & $\begin{array}{l}\text { Product capabilities are entirely left to the } \\
\text { designer, and the capabilities are limited to } \\
\text { hardware constraints } \\
\text { and the system designer. }\end{array}$ \\
\hline Remote Access & $\begin{array}{l}\text { It is possible with remote control modules } \\
\text { added to control panels. }\end{array}$ & $\begin{array}{l}\text { The system structure is based on remote } \\
\text { access. }\end{array}$ \\
\hline Entegration & $\begin{array}{l}\text { It is mandatory to use the software provided } \\
\text { by the company that produces the control } \\
\text { panel. }\end{array}$ & $\begin{array}{l}\text { Since the software platform is independent, it } \\
\text { can be integrated into any software system. }\end{array}$ \\
\hline Maintenance & $\begin{array}{l}\text { There are warnings for standard } \\
\text { maintenance operations with parameters set } \\
\text { in the panel. Fault } \\
\text { prediction is not possible. }\end{array}$ & $\begin{array}{l}\text { In addition to the competencies in the control } \\
\text { panel, it is possible to apply predictive } \\
\text { maintenance techniques. }\end{array}$ \\
\hline Performance & $\begin{array}{l}\text { Product performance is not subject to } \\
\text { evaluation, no data is recorded. }\end{array}$ & $\begin{array}{l}\text { The system can be monitored continuously } \\
\text { for error / malfunction prevention measures } \\
\text { and the manufacturer can be contacted. All } \\
\text { data in the system can be recorded and } \\
\text { evaluated retrospectively and } \\
\text { used for new product development. }\end{array}$ \\
\hline
\end{tabular}

When the literature is examined, it is seen that the applications are generally on small scale environmental measurements and building automation systems. In addition to this, different applications for medical sector, agriculture sector, transportation sector and other sectors are available in the literature (Çakmak and Mercan, 2017; Sazak and Albayrak, 2017; Pereiraa et al., 2018; Fioccola et al., 2016; Eryılmaz et al., 2016). Integrated prototype applications have been developed in the structures that generally use micro-controllers with 8-bit architecture and limited memory capacity. In these applications, pressure, temperature, humidity, current, voltage, etc. measured by sensors are used with the help of a gateway of physical quantities, real-time monitoring and control structure over the web. In addition, there are fewer studies using cloud services for storage and real-time monitoring to overcome the limited data storage problem (Y1lmaz and Acar, 2017).

Smart watches, implants and wearable technologies that make your life easier with daily watches have been examined by Çakır ve ark. The big data problem consisting of data security and continuous data storage has been evaluated with IoT structure (Çakır et al., 2018). The advantages of real-time data monitoring, retrospective data analysis and predictive maintenance of cloud-based structures and the IoT used in applications such as renewable energy and smart grids have come to the fore (Çăglayan, 2016).

Pereiraa et al. addressed the problem of real-time remote monitoring and storage of large amounts of data for IoT and cloud-based systems for distributed structures with multiple stations, such as a photovoltaic power plant (Pereiraa et al., 2018).

In a successful prototype application for the measurement and remote monitoring of air pollution, different communication protocols (REST API and MQTT) were examined in terms of latency of data 
transmission (Fioccola et al., 2016). In another application, Azure cloud platform was compared with different cloud platforms. Advantages of cloud platforms compared to each other were evaluated.

At this point, cloud server selection in cloud-based applications varies according to the needs of the system designer and server services. Cloud servers and visualization-reporting services can work together, support for different operating systems such as Linux, Windows, IOS, features such as updating software and services play an active role in system design. In another study, by comparing the cloud performance, it was determined that the system response was below $1150 \mathrm{~ms}$ with 600 data update rate in $1 \mathrm{~s}$ over 1500 sensors. If the number of sensors is below 500, it is determined to be less than $0.1 \mathrm{~ms}$ (Forsström and Jennehag, 2017; Çağlayan, 2016).

In addition to communication protocols, data security is very important for this new concept. In IoT applications, starting from the sender side, the content of the message, the environment in which the message is broadcast and the message recipient must be secured. The sent messages and data must be encrypted so that they cannot be accessed by others, and it must be checked whether the message has been changed from the moment it reaches the recipient (Görmüş et al., 2017). Microsoft, for security reasons, the preferred Microsoft Azure platform provides data transmission between IoT devices with a key of 88 ASCII characters and over the "HTTPS" protocol (Microsoft, 2017).

Real-time remote monitoring and performance evaluation is very important for generator systems that vary in nature by location, especially in harsh operating conditions and remote locations. Real-time monitoring, which is usually provided with existing control panels, has problems such as inflexible and limited access structure with the interface software provided by the control panel manufacturers.

In this study, a real - time performance analysis of a widely used generator system in the industry was performed using cloud - based IoT. In the performed application, the measurements provided by using the sensors connected to the generator are displayed on site with HMI display. The critical data of the system was firstly sent to the cloud platform via Node-RED software with the help of Raspberry $\mathrm{Pi}$ and it was ensured that it was monitored on the web with the help of Power BI. All data recorded on the cloud were used for performance evaluation. In addition, cloud-based IoT application is provided as OPC based with the control structure developed with Labview software as a second method.

\section{MATERIALS AND METHODS}

In this study, internet of cloud computing based objects has been implemented on generator system. The system is an industrial IoT and a cloud-based application and contains the two most important structures of the Industry 4.0 transformation components. The preferred generator in the system has a 3-phase, $1500 \mathrm{rpm}$ synchronous alternator driven by an internal combustion engine and has a standby power of $30 \mathrm{kVA}$. In generator control system, voltage, current, frequency, alternator and oil temperature etc. sensors are available where measurements are provided. Figure 2 gives an overview of the diesel generator structure and control system.

Programmable logic controller (PLC) was used to monitor the generator system. The PLC used has a total of 28 digital inputs / outputs and measurements were taken by adding temperature and analogue measurement modules. Temperature measurement with DVP 04TC thermocouple module and analog signal measurement with DVP 06AD extension module. An HMI display was used for local monitoring and control. The HMI display has a resolution of 800x480 and supports RS232 / RS422 / RS485 communications. In addition, fault and alarm conditions are defined on the HMI display.

Microsoft Azure platform, which is widely used as a cloud service provider and has many different services, was preferred in the study. The Azure cloud platform is highly scalable, provides 
server support in different geographic regions, offers web-based optimization for mobile devices, and supports machine learning.

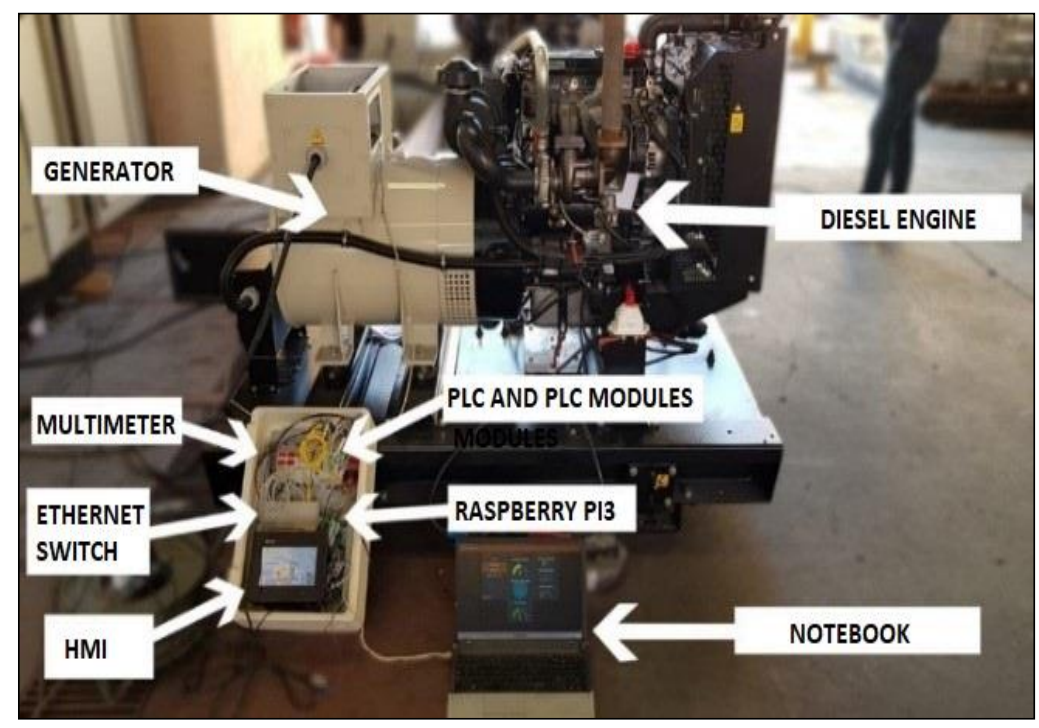

Figure 2. Experimental setup for diesel generator.

\section{Application Structure}

Two different methods are used to send the data to the cloud system and to store and monitor it on the web.

\section{a) Application structure with Node-RED software}

In the first method, the hardware structure of Raspberry Pi3 was used as the main controller and gateway. Node-RED is the software that runs on Raspberry Pi3. With Node.js based Node-RED, data on PLC measurement system was obtained by using Modbus protocol with Rs-485 standard and sent to Microsoft Azure cloud platform. Interface design for the user is provided with the help of Nod-RED and the cloud platform application (PowerBI). All data were monitored over the internet using different hardware platforms (mobile phone and mobile computer). Figure 3 shows the structure of the system.

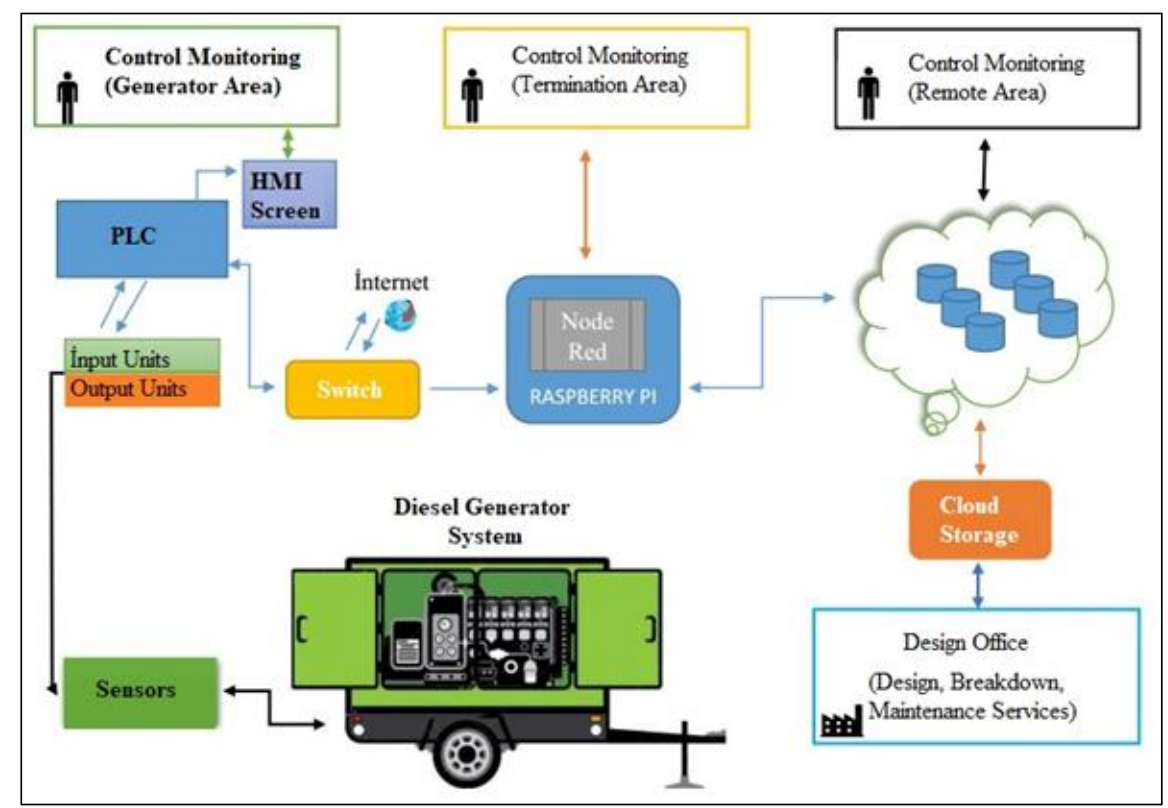

Figure 3. Structure of the system designed for the first method. 
In the first method, the sensor data in the generator system was read from the modbus registers of the PLC via Modbus TCP / IP communication by means of Node-RED software. In addition to the use of predefined nodes and libraries in the Node-RED software, the functionality of the program is provided with JavaScript code. Figure 4 shows the diagram of the program created in Node-Red software. In the diagram given, communication nodes are used for taking measurements from PLC, indicator nodes for visualizing measurement data on the user side, and cloud nodes for sending data to the cloud platform via MQTT protocol.

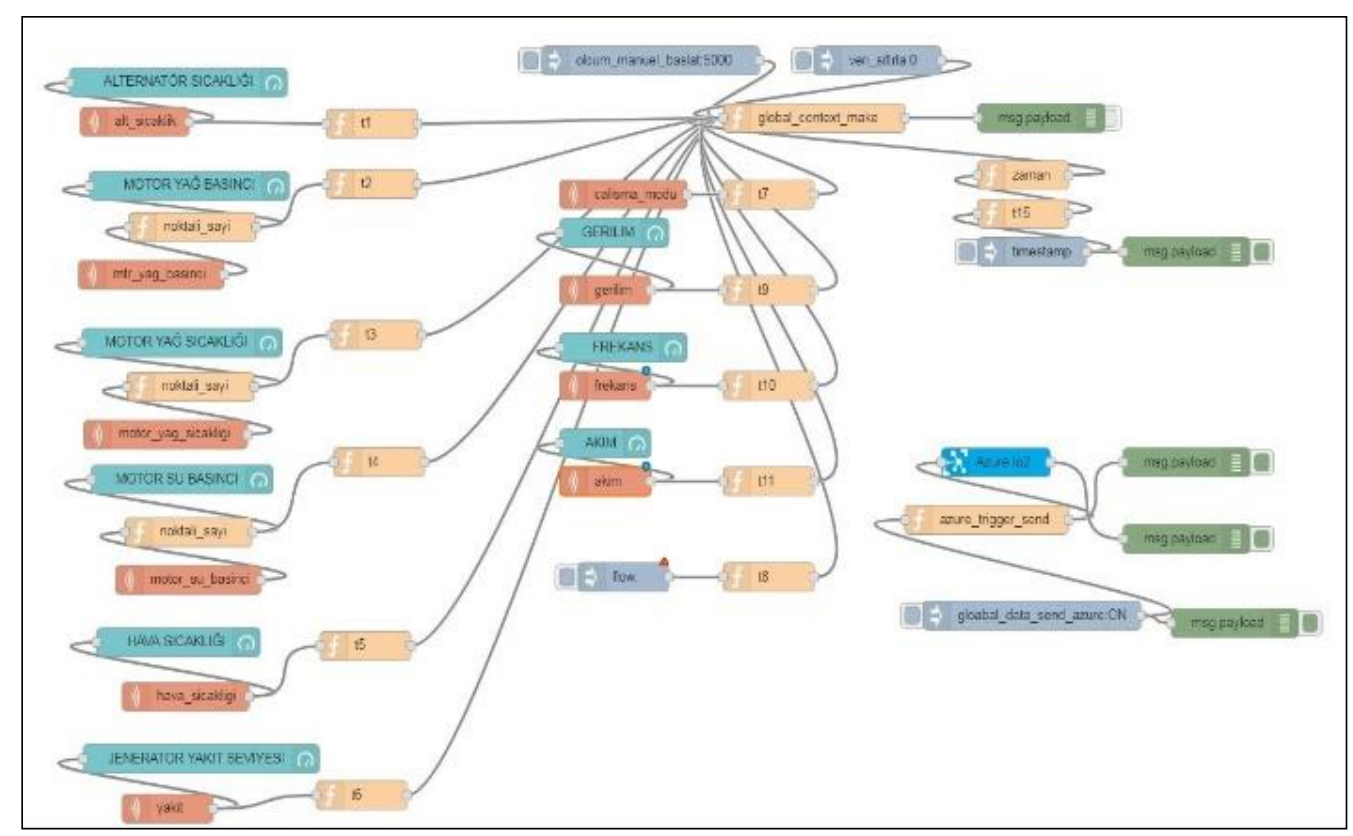

Figure 4. Node-Red software nodes.

Communication between cloud and Raspberry Pi3 gateway is provided by MQTT protocol. The MQTT protocol is a communication protocol based on the logic of broadcasting and subscribing to published messages. It is widely used in a secure manner since a desired device can subscribe to published messages (MQTT Community, 2019).

The first part of the data sent from the Raspberry Pi3 to the cloud platform is the Azure IoT Hub service. Data from IoT Hub service is stored in the Blob Storage area in the cloud. An interface design was carried out with Microsoft PowerBI software for visualization of all data in real time. PowerBI is a set of services that enable both instant analysis and visualization of data instantly and efficiently over desktop and web (Microsoft, 2019).

\section{b) Labwiew Application}

In the second method, a laptop was used as gateway and master controller and Labview was used as software. Measurement, transfer of measurement data to the cloud and interface design are made with this program. Labview software has been preferred due to the limitations of Power BI and Node-RED software in interface development and also Labview has a powerful analysis, calculation and reporting libraries.

With Labview, sending data to the cloud platform, uploading data from the cloud platform, and querying data were performed through a single software structure. Figure 5 shows the Labview softwarebased system structure. 


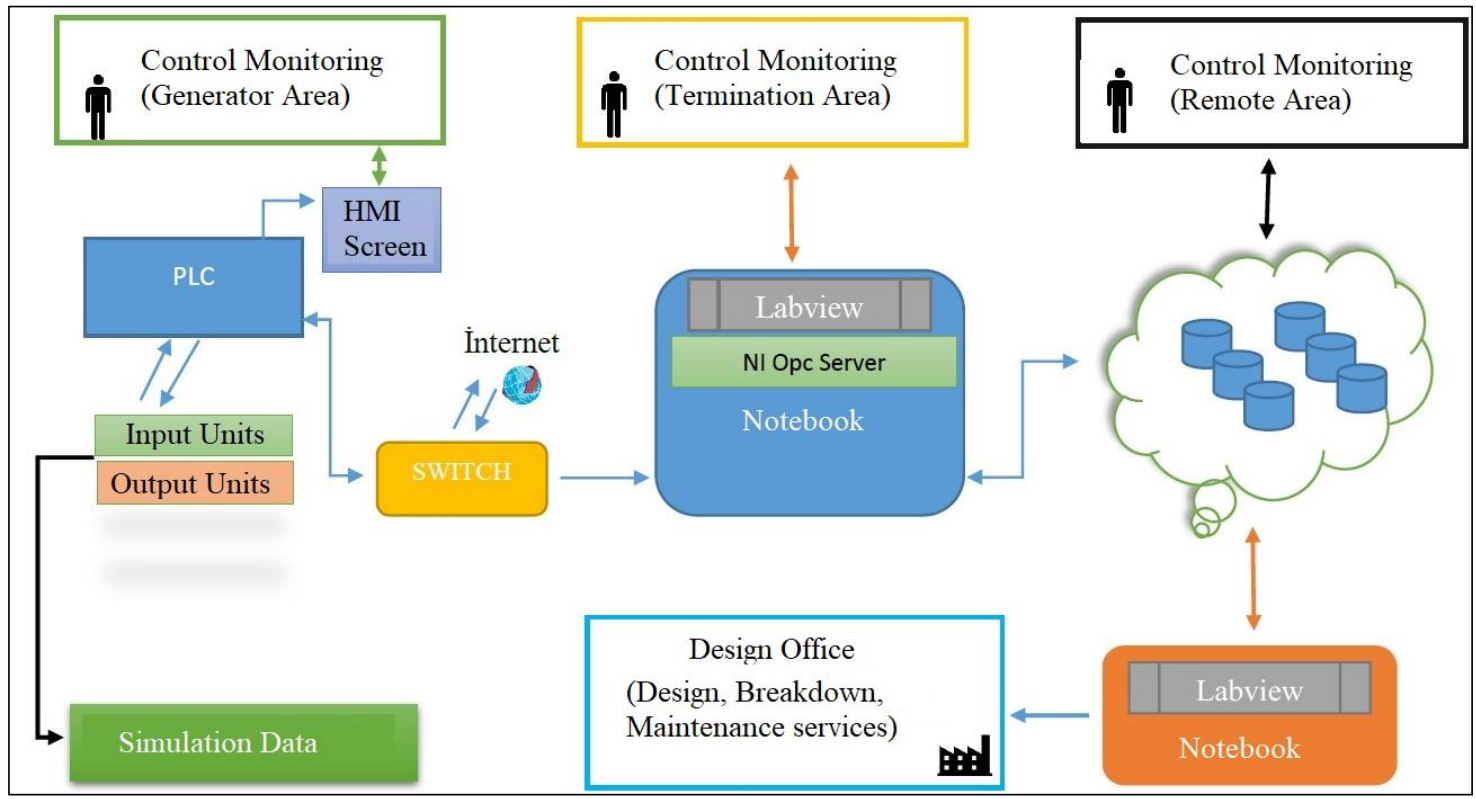

Figure 5. System model used in the second method.

In the second method, the measurement data obtained from the generator system was read from the PLC registers by using Modbus TCP / IP communication using OPC software. Figure 6 shows the addressing structure created with OPC software. In this way, data can be read from PLC addresses and transferred to Labview software.

\begin{tabular}{|c|c|c|c|c|c|c|}
\hline \multicolumn{4}{|l|}{$\begin{array}{l}\text { बc OPC Quick Client-Untitled * } \\
\text { File Edit View Tools Help }\end{array}$} & \multirow[t]{2}{*}{-} & \multirow[t]{2}{*}{$\square$} & \multirow[t]{2}{*}{$\times$} \\
\hline \multicolumn{4}{|l|}{ 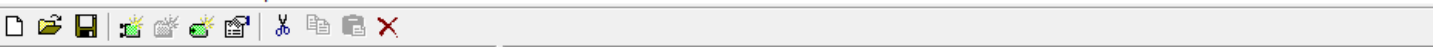 } & & & \\
\hline \multirow{11}{*}{$\begin{array}{l}\text { National Instruments.NIOPCServers.V5 } \\
\square \text { Chstem } \\
\text { Channel_delta_12se._CommunicationSerialization } \\
\text { Channel_delta_12se._Statistics } \\
\text { Channel_delta_12se._Device1 } \\
\text { Channel_delta_12se.Device1._Statistics } \\
\text { Channel_delta_12se.Device1._System }\end{array}$} & Item ID & \begin{tabular}{l|l} 
Data Type \\
\end{tabular} & Value & & & \\
\hline & ØChannel_delta_12se.Device1.akim & Word & 30 & & & \\
\hline & ØChannel_delta_12se.Device1.altematorsicakligi & Word & 90 & & & \\
\hline & DChannel_delta_12se.Device1.calismasaati & Word & 7 & & & \\
\hline & DChannel_delta_12se.Device1.frekans & Word & 52 & & & \\
\hline & Channel_delta_12se.Device1.gerilim & Word & 220 & & & \\
\hline & CChannel_delta_12se.Device1.havasicakligi & Word & 28 & & & \\
\hline & DChannel_delta_12se.Device1motorsubasinci & Word & 2 & & & \\
\hline & •Channel_delta_12se.Device1.motoryagbasinci & Word & 2 & & & \\
\hline & ØChannel_delta_12se.Device1.motoryagsicakligi & Word & 110 & & & \\
\hline & Channel_delta_12se.Device 1.yakitseviyesi & Word & 80 & & & \\
\hline
\end{tabular}

Figure 6. Reading data from PLC with modbus TCP / IP using OPC Software.

For each measurement variable (Current, Voltage, Frequency, etc.) created in OPC software, global variables were created in Labview software and the measurement data were transferred to Labview software with the help of Modbus TCP / IP. In this way, data is visualized on the interface screen designed for the user with Labview software. In addition, this data is sent to Azure platform simultaneously with the help of Azure toolkit module.

For sending data from Labview software to Azure cloud system, "Storage Account Name" and "Access Key" information, which is provided to the user by Microsoft and has a unique identity, is defined in the program. The measurement data is stored at regular intervals within the Queue fields. Figure 7 shows the structure of the program instead of the functions mentioned below. 


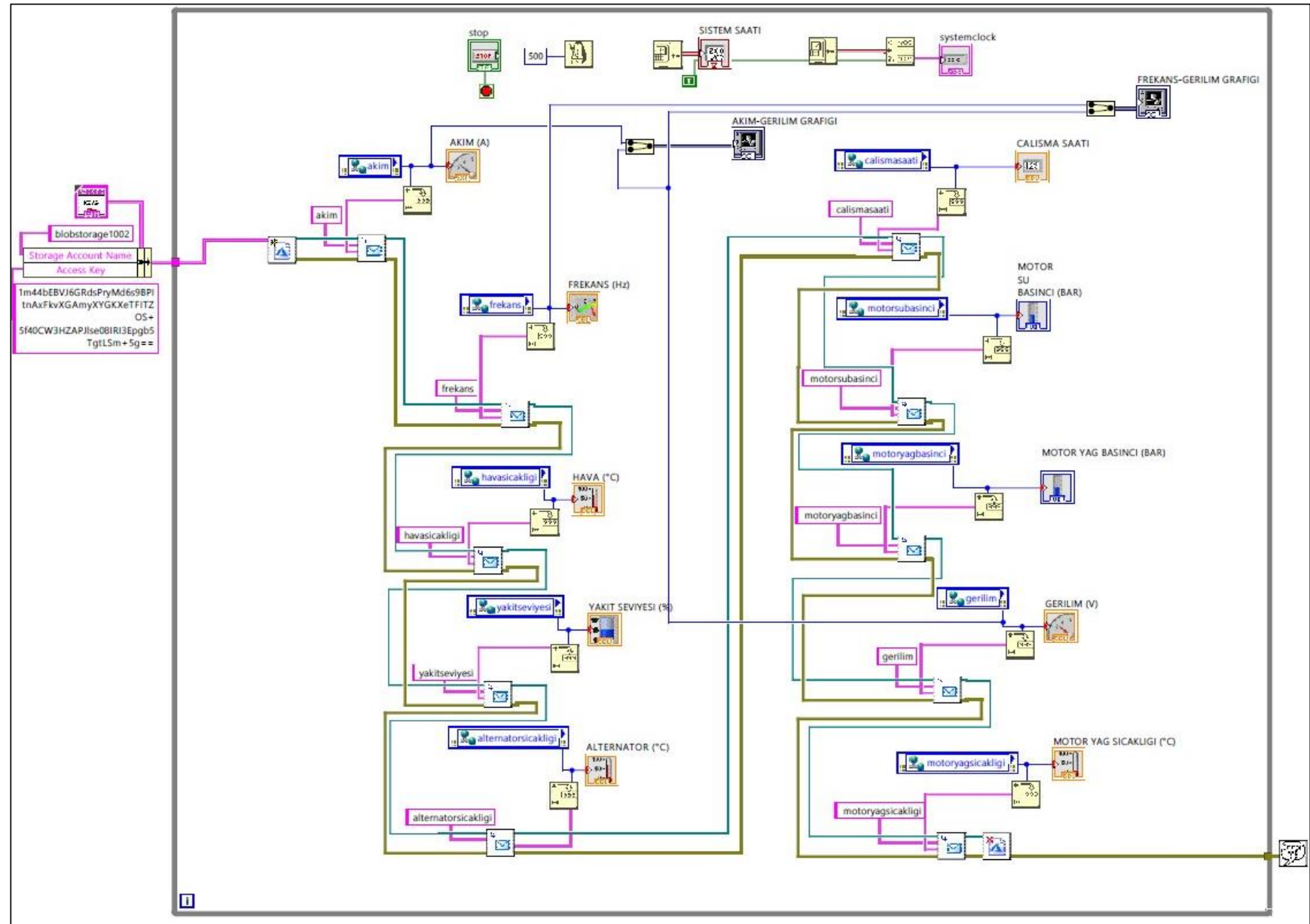

Figure 7. Send data to Azure Queue in Labview.

With the other interface created in Labview software, the data stored on the cloud platform is downloaded and transferred to the user computer. As in the process of sending data, "Account Name" and "Access Key" were used. The program part required for reading the data from the Queue field is given in Figure 8. At the same time, global variables were defined and visualization of the data was made for the graphs of each data to be monitored.

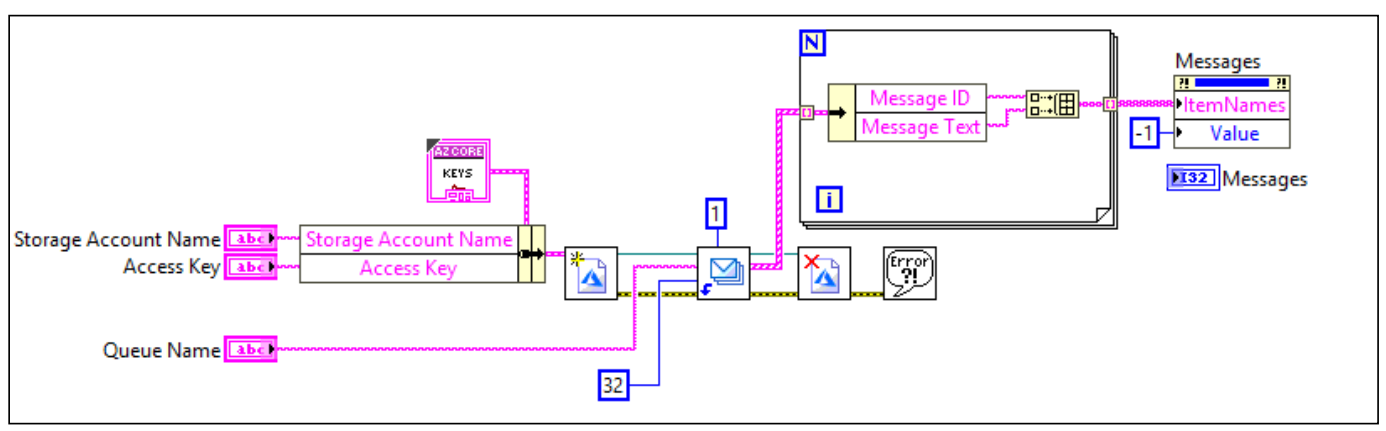

Figure 8. List of posts in Labview, Queue.

\section{RESULTS AND DISCUSSION}

Generators main or backup power support system are widely used in many applications. Monitoring of the generator system on site is important in order to provide a quick and easy solution for possible failures. We designed HMI screen for this propose is given in Figure 9. Generated voltage, current, frequency of critical data such as monitoring on-site, user-friendly screen structure is provided. 
At the same time, the defined warning and alarm structures provided technical support personnel the opportunity to develop easy and fast solutions for fault monitoring.

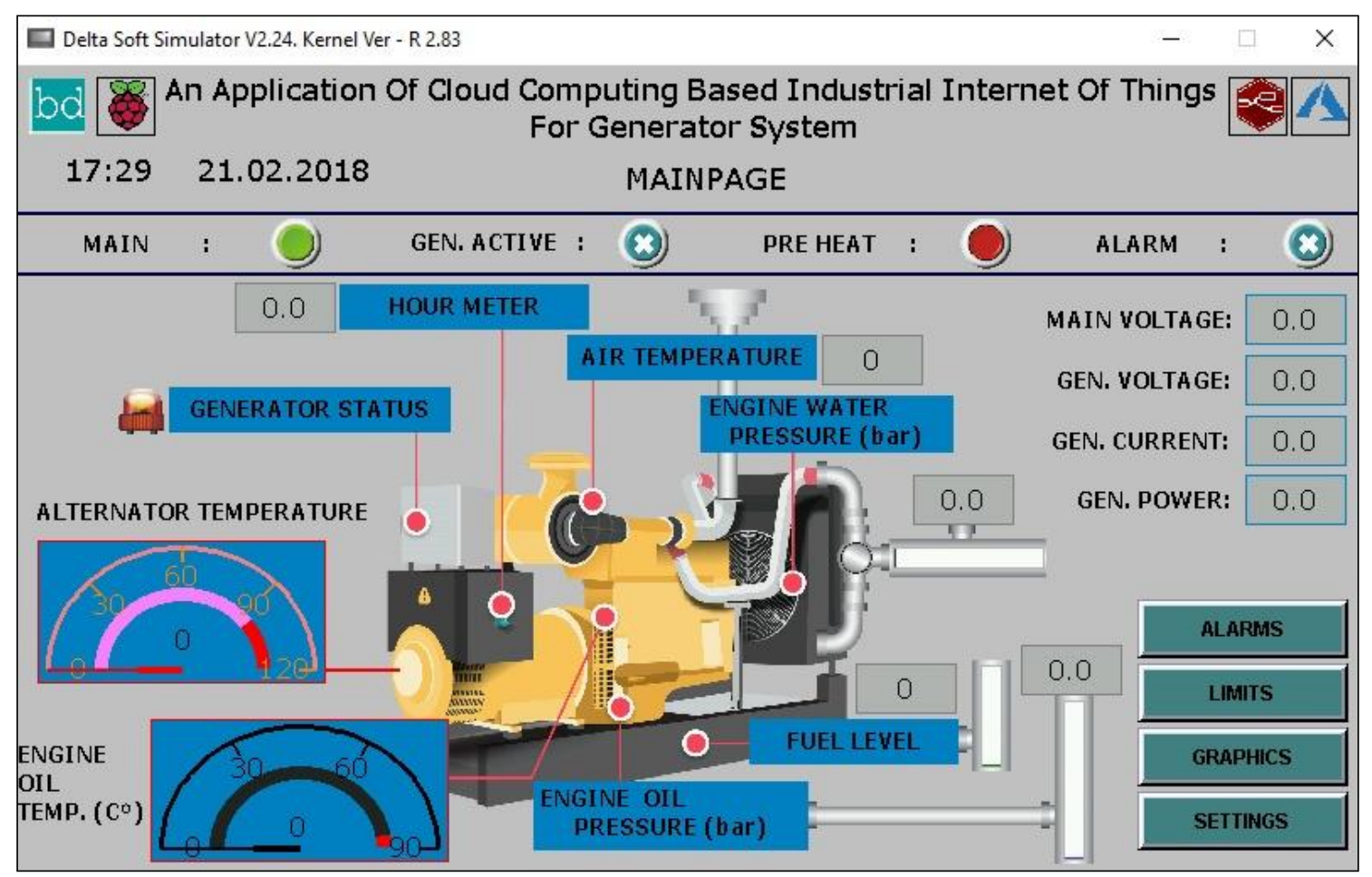

Figure 9. User Interface of HMI display for generator.

High-low oil pressure, high water temperature, high water pressure warnings are defined on the side of the diesel engine that provides mechanical drive as well as electrical data such as high-low voltage and high current for the alternator in the generator. These fault descriptions provide information for the purpose of retrospective inspection and improvement of the generator's frequency, fault cause and time of occurrence.

In the first method, the interface for monitoring data was designed with Node-RED. This interface provides web access via the IP address of Raspberry Pi3. The interface developed for performing this function is given in Figure 10. HMI display allows user access to the measured data displayed on the web via this interface.

Node-RED software includes a section that allows automatic or manual control of the generator system, a section where generator parameters and internal combustion engine parameters are measured, and a section where generator operating hours are displayed.

The advantages of Node-Red software; it can be used as open source software in Linux and Microsoft operating system, working on different platforms such as desktops, notebooks and mobile phones. However, it is not flexible in terms of data analysis, visualization and reporting. It does not have an integrated database, especially for database applications. The database structure needs to be integrated into the software separately. Ip routing is also required to access the interface designed in Node-RED software. 


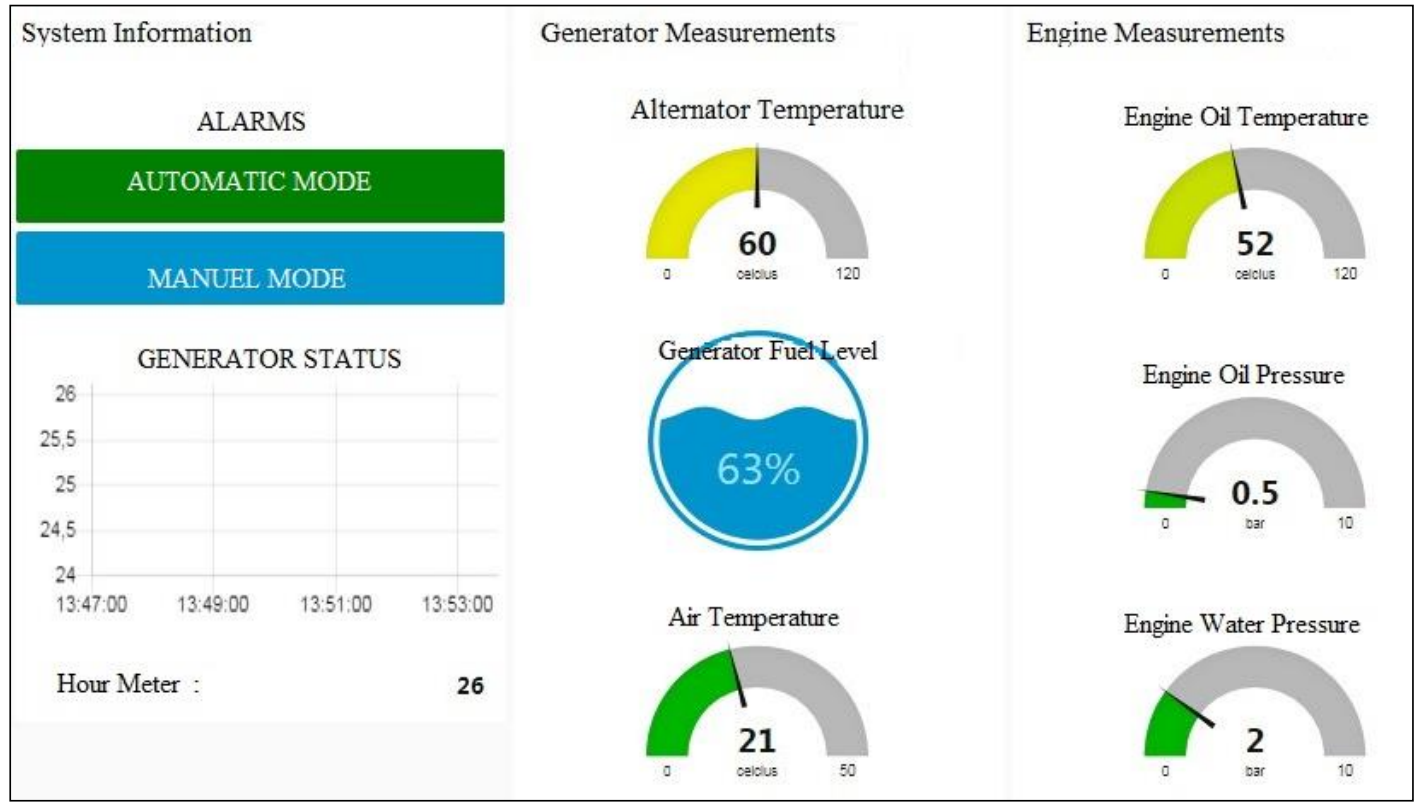

Figure 10. User interface created in Node-Red software.

Microsoft PowerBI software which has advantages such as data analysis and structure which does not require any port forwarding, has been used to visualize and monitor data in real time. The interface prepared in the software hosting the paid services is given in Figure 11. Using this interface, it is possible to check whether the system meets the required performance criteria by using the user interface and the recorded data over the internet, without the need for customer participation in the field tests. In addition, it was ensured that the data obtained previously through observation in the system were transferred to the digital media and saved automatically by saving personnel and time.

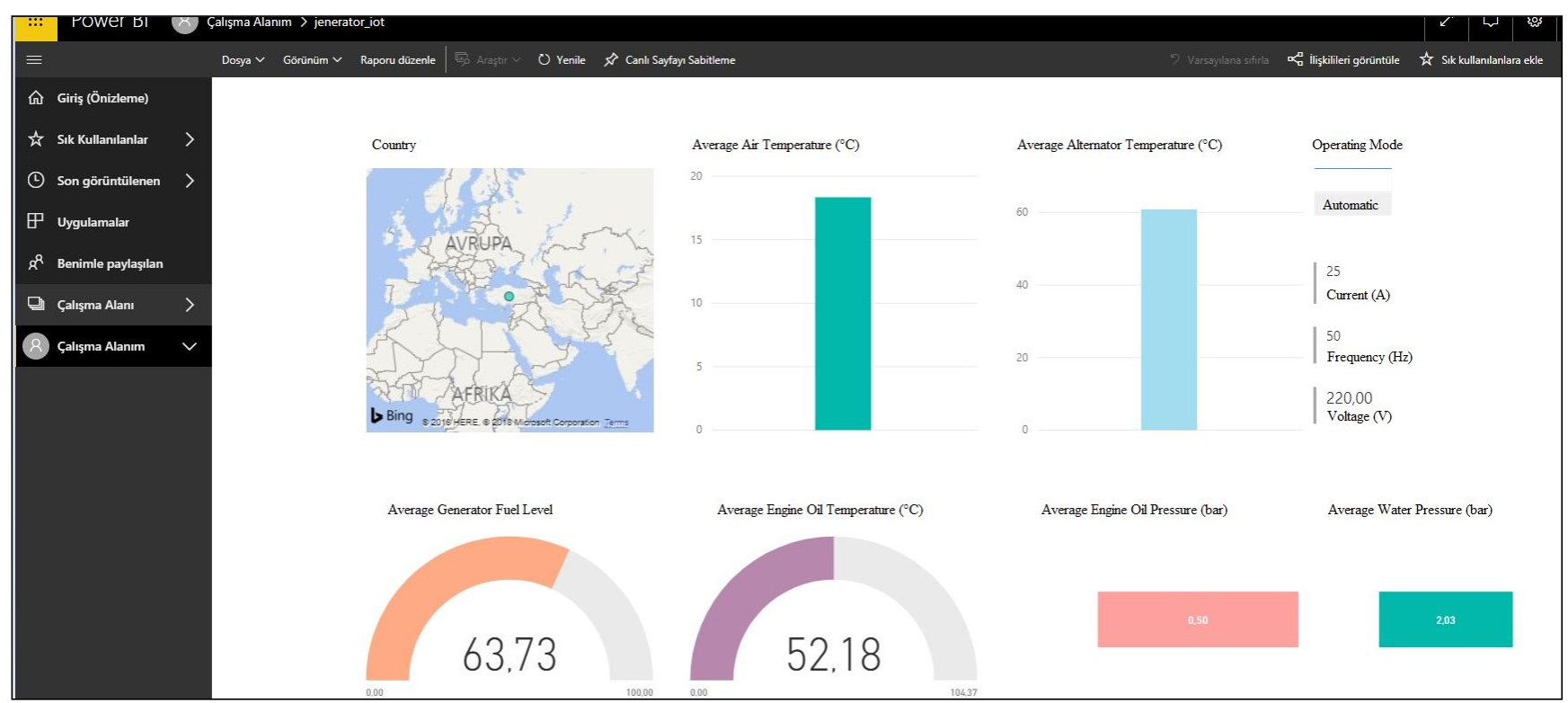

Figure 11. User-interface prepared in PowerBI platform.

Two different software such as Node-RED and Power BI were used for measuring, visualizing, sending to the cloud platform, uploading from the cloud platform and visualizing the data received from the cloud in real time. Labview software has been used to overcome the limitations of Node-RED software in interface design and the inflexible software structure of Power BI. At this point, Labview is 
used as software and two different interface designs are carried out. With the interface given in Figure 12 , measurements can be displayed and sent to the cloud platform.

With the first interface carried out in Labview software, it is provided to display the data of the generator system, while the second interface enables downloading and viewing the data stored on the cloud platform.

The monitoring of Labview interface screen over the web was performed with the full structure of REST with Labview Web Service.

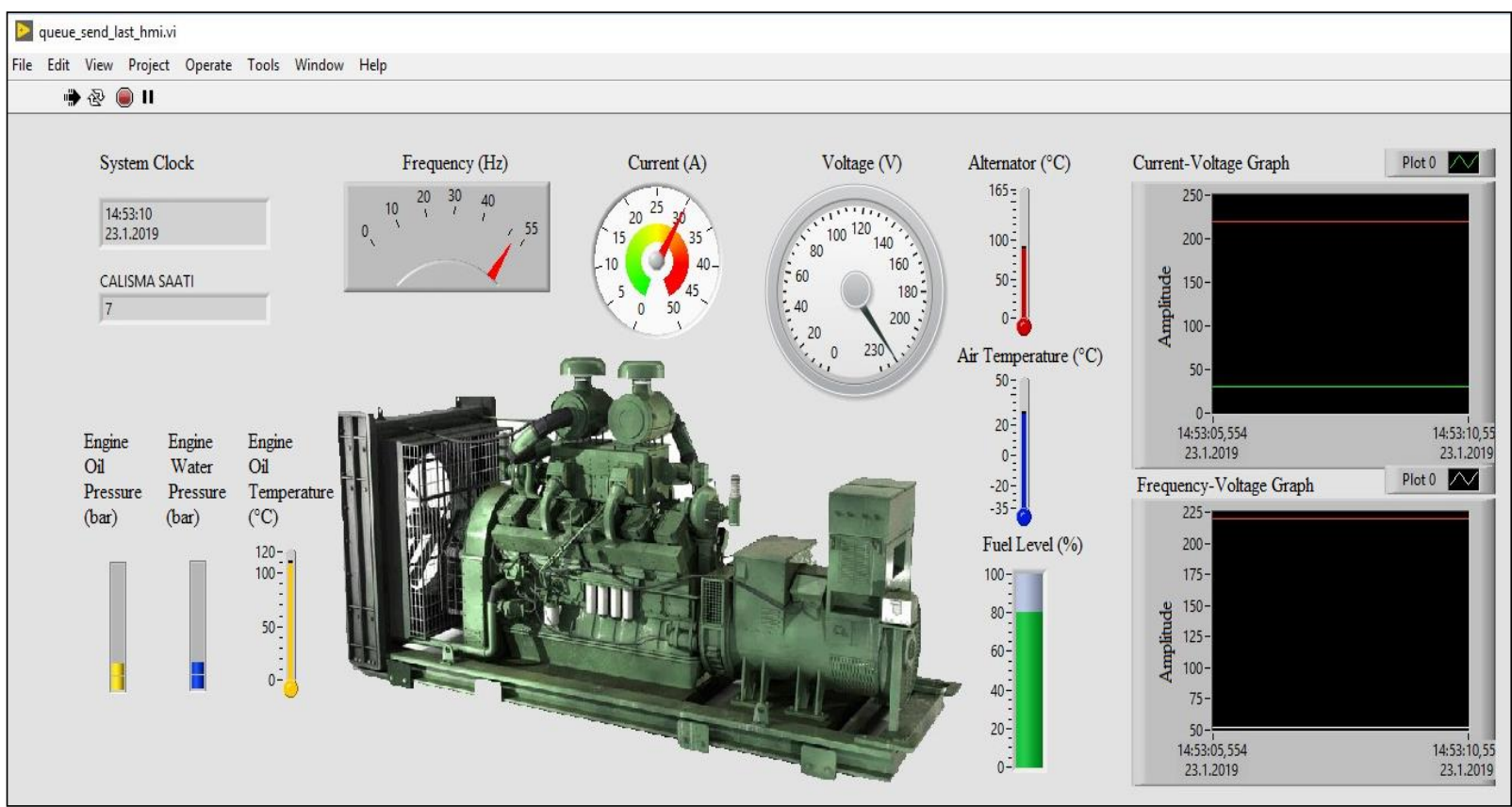

Figure 12. Screenshot of Labview user interface.

Figure 13 shows the interface for downloading and simultaneously viewing data on the cloud platform for the user.

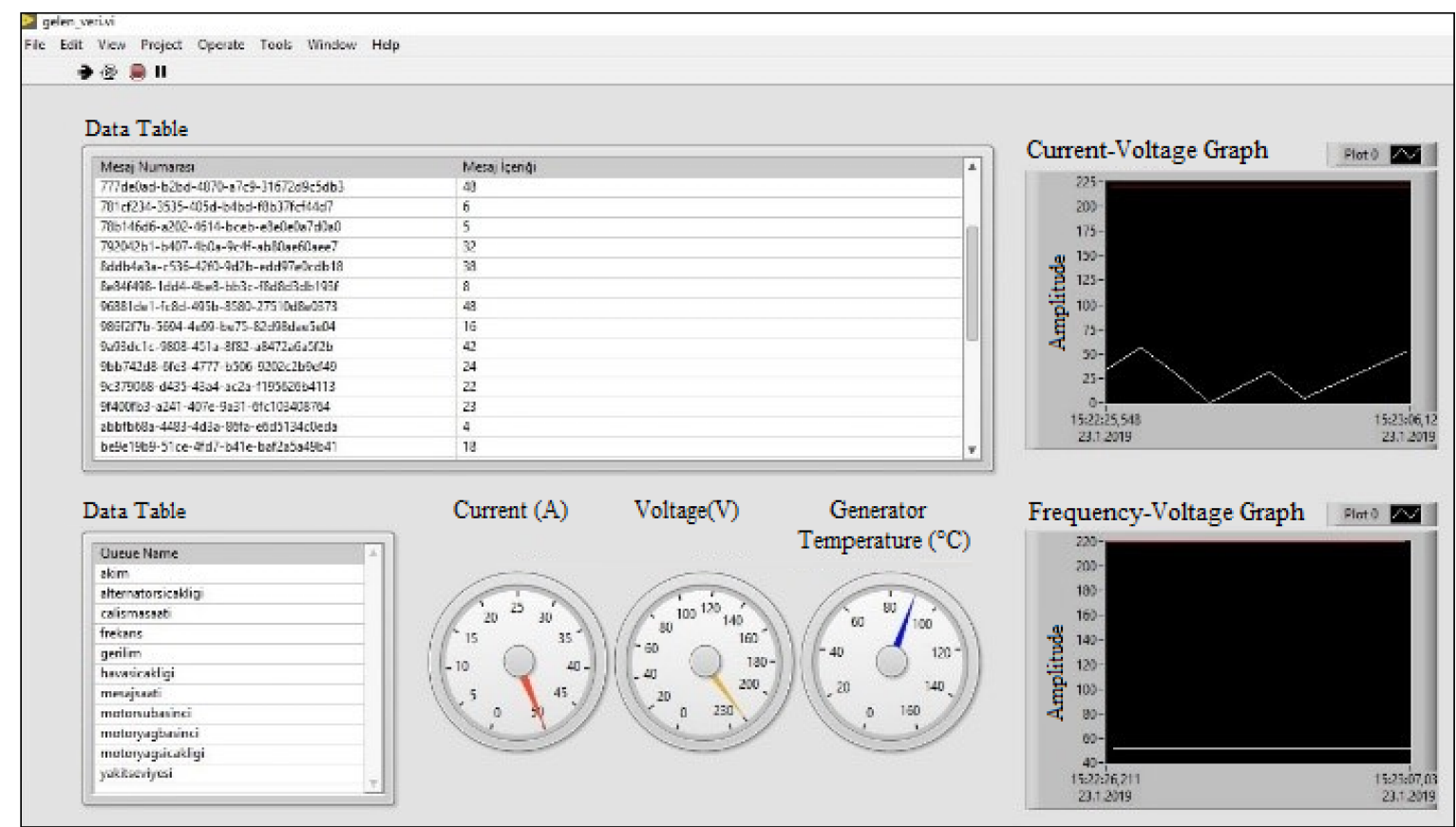

Figure 13. Labview interface for monitoring the data. 
The data recorded in the cloud can be used in the analysis process for the performance evaluation of the generator system. The engine temperature and pressure of the generator in the system designed for this purpose are made by transferring the data of the current to the Microsoft Excel software. The performance graph is given in Figure 14.

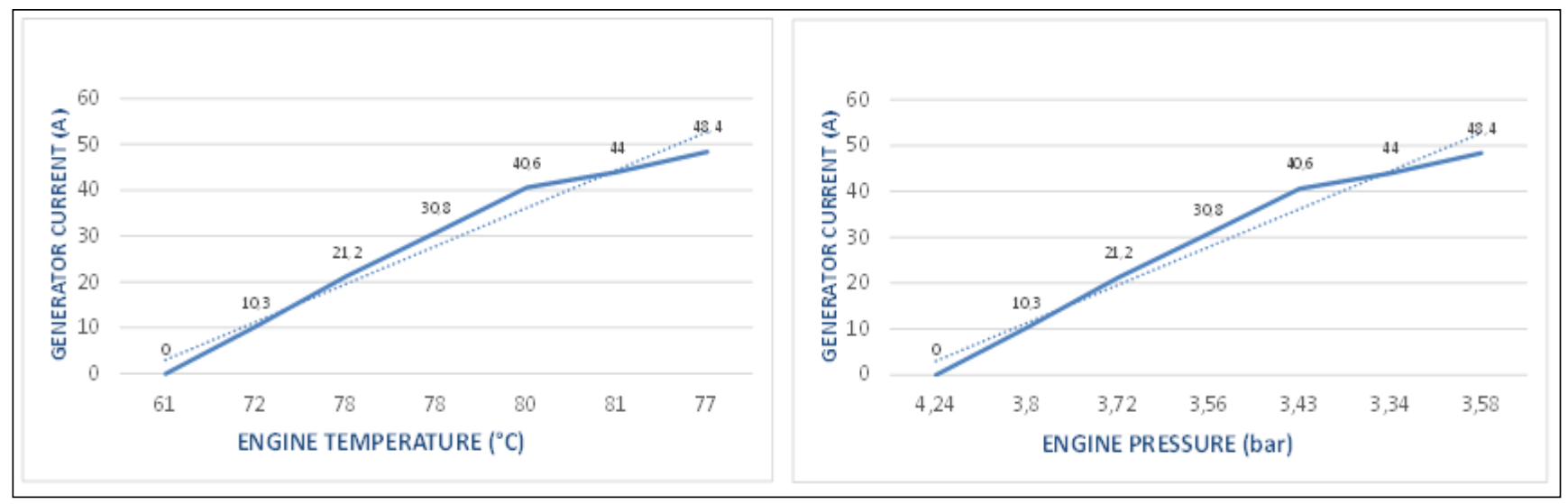

Figure 14. Generator system, performance measurements.

\section{CONCLUSION}

In this study, cloud based IoT structure is used for remote monitoring of a generator. With the help of the realized system, the limitation of the electronic control panel in the generator structure has been exceeded. The remote control and performance evaluation of the generator has been made over the internet with the help of developed interfaces. Node-Red, PowerBI and Labview platforms have different interface designs and data visualization and reporting processes have been provided. A comparison was made for each interface.

All data were recorded on the cloud and analyzed retrospectively. Thanks to Power BI mobile application support, it is possible to monitor the system by designing the interface for mobile devices with Android operating system. HMI interfaces can be used for on-site monitoring, control and fault monitoring of the system. With these designs, critical data, alarm conditions and errors in the diesel generator are displayed.

Thanks to this developed system, customers can carry out performance and inspection tests online via remote access provided over the internet without being in the factory acceptance tests. In this way, serious gains can be achieved in terms of time and costs.

\section{ACKNOWLEDGMENT}

We would like to thank ISSBİR Elektrik San. A.Ş. AR-GE Merkezi for their contribution to the study.

\section{REFERENCES}

Botta A, Donato W, Persico V, Pescape A, 2016. Integration of Cloud Computing and Internet of Things: A Survey. Future Generation Computer Systems, 684-700.

Brette M, Friederichsen M, Keller M, Rosenberg M, 2014. How Virtualization, Decentralization, And Network Building Change The Manufacturing Landscape: An Industry 4.0 Perspective. Journal of Mechanical, Aeorospace, Industrial, Mechatronic and Manufacturing Engineering, 37-44. Çağlayan Ş, 2016. Enerji Sektöründe Endüstriyel IOT Uygulamaları. https://www.slideshare.net/ideaport_tr/enerji-sektrnde-endstriyel-iot-uygulamalar-ahin-alayan, (Date of access: 11 July 2019). 
Çakır FS, Aytekin A, Tümiçin F, 2018. Internet Of Things And Wearable Technologies. Journal Of Social Research and Behavioral Sciences, 4, 5, 84-95.

Çakmak B, Mercan E, 2017. Example of IoT application in agricultural production and the traceability of elderly agricultural workers. Elderly Issues Research Journal, 10, 1, 29-42.

Eryılmaz Ö, Kahraman İ, Şahin M, 2016. Cloud-Computing Based Early Warning System For Cardiac Emergencies. Çanakkale Onsekiz Mart University, Journal of Graduate School of Natural and Applied Sciences, 01-19.

Fioccola GB, Sommese R, Tufano I, Canonico R, Ventre G, 2016. Polluino: An Efficient Cloud-based Management of IoT Devices for Air Quality Monitoring. Control, Instrumentation, Energy \& Communication (CIEC).

Fioccola GB, Tufano I, Canonico R, Ventre G, 2016. An Efficient Cloud-Based Management of Iot Devices for Air Quality Monitoring. IEEE 2nd International Forum On Research and Technologies for Society and Industry Leveraging a Better Tomorrow, Italy.

Forsström S, Jennehag U, 2017. A Performance and Cost Evaluation of Combining OPC-UA and Microsoft Azure IoT Hub into an Industrial Internet-of-Things System. 2017 Global Internet of Things Summit (GIoTS), Switzerland.

Görmüş S, Aydın H, Ulutaş G, 2017. Security for the internet of things: a survey of existing mechanisms, protocols and open research issues. Journal of the Faculty of Engineering and Architecture of Gazi University, 18-1.

Gündüz M, Daş R, 2017. Internet of things (IoT): Evolution, components and applications fields. Pamukkale University Journal of Engineering Sciences, 327-335.

Lin K, Wang W, Bi Y, Qiu M, Hassan MM, 2016.Human Localization Based On Inertial Sensors and Fingerprints in The Industrial Internet of Things. Computer Networks: The International Journal of Computer and Telecommunications Networking, 113-126.

Microsoft, 2017. Paylaşılam erişim imzaları (SAS) kullanma, https://docs.microsoft.com/trtr/azure/storage/common/storage-dotnet-shared-access-signature-part-

1?toc $=\% 2$ fazure $\% 2$ fstorage $\% 2$ ffiles $\% 2$ ftoc.json, (Date of access: 12 June 2019).

Microsoft, 2019. Power BI nedir?, https://docs.microsoft.com/tr-tr/power-bi/power-bi-overview, (Date of access: 21 June 2019).

MQTT Community, 2019. What is MQTT, http://mqtt.org/faq, (Date of access: 12 June 2019).

Numanoğlu N, İnce F, 2017. Türkiyenin Sanayide Dijital Dönüşüm Yetklinliği. TÜSİAD, 12-589.

Numanoğlu N, Eynehan G, Morkoç G, Aksoy E, 2016. Industry 4.0 in Turkey as an Imperative for Global Competitiveness. Turkish Industry and Business Association (TÜSİAD), 03-576.

Pereiraa RIS, Duponta MI, Carvalhoa PCM, Jucáb SCS, 2018. Iot Embedded Linux System Based On Raspberry Pi Applied to Real-Time Cloud Monitoring of a Decentralized Photovoltaic Plant. Measurement, 286-297.

Sazak T, Albayrak Y, 2017. Nesnelerin İnterneti (IoT) Üzerine Ortam Verilerini Toplayan ve Uzaktan Takibini Sağlayan Bir Sistem Tasarımı. 19.Akademik Bilişim Konferansı, Aksaray, Türkiye.

Y1lmaz AK, Acar DB, 2017. Real Time and Scalable Big Data Architecture for IoT Data. Proceedings of the 11th Turkish National Software Engineering Symposium, Alanya, Turkey. 